\title{
Pengaruh Perkembangan Kehidupan Masyarakat terhadap Pengaturan Hukum tentang Aborsi di Indonesia
}

\author{
Paulinus Soge
}

\begin{abstract}
The purpose of this article is neither to explore the evolution of US Supreme Court doctrine concerning abortion, nor to discuss about the controversy on abortion issue occurred at The Intemational Conference on Population and Development (ICPD) in Cairo in September 1994. The discussion is directed to the area of legal policy to anticipate a legal change on abortion in Indonesian Penal Law from "illegal" to "legal" under certain requirements (safe abortion) to prevent women doing unsafe abortion resulting in increasing number of maternal death. To design such an abortion law in Indonesia it is recommended to leam the development of abortion law in various countries especially after the ICPD.
\end{abstract}

\section{Pendahuluan}

Aborsi telah menjadi masalah kontroversial sejak Mahkamah Agung Amerika Serikat menjatuhkan putusan dalam kasus Roe v. Wade ${ }^{1}$ pada tahun 1973 yang menetapkan bahwa wanita mempunyai hak berdasarkan Undang-undang Federal untuk melakukan aborsi. Sejak itu para aktivis mulai menentang validitas Undang-undang Aborsi, dan perjuangan mereka membawa hasil ketika Mahkamah Agung Amerika Serikat dalam kasus Roe and Doe v. Bolton 2 menetapkan bahwa hukum aborsi Texas dan Georgia inkonstitusional.

Kedua putusan Roe tersebut merupakan kemenangan bagi kubu pro-aborsi, namun putusan tersebut mendapatkan reaksi yang luas dari kubu kontra-aborsi, sehingga hal ini baru merupakan awal dari perjuangan yang

'Alber M. Pearson, J.D. and Paul M. Kurtz, J.D. 1973. "The Abortion Controversy: A Study in Law and Politics." Dalam J. Douglas Butler and David F. Walbert. (Eds)." Abortion, Medicine, And The Law, Third Ed".HIm. 107.

2lbid. 
melelahkan bagi kubu pro-aborsi melawan prinsip yang fundamental menyangkut sikap pro-life yang dianut kubu kontra-aborsi.

Kontroversi mengenai masalah aborsi terus berkelanjutan dan jelas terlihat dalam Konferensi Internasional Penduduk dan Pembangunan di Kairo tahun 1994, antara Takta Suci, satu-satunya lembaga keagamaan yang mempunyai wakil resmi di PBB di satu pihak, melawan wanita yang mempunyai hak untuk menentukan nasib sendiri di lain pihak. Dalam hal ini adalah absurd untuk memandang enteng pengaruh Vatikan atas pemerintah di banyak negara atau kemampuannya untuk menggalang aliansi dengan golongan agama atau kekuatan konservatif lainnya di dalam konferensi internasional tersebut atau di dalam konferensi-konferensi internasional lainnya seperti konferensi internasional mengenai'hak asasi manusia dan kejahatan perang.

Dengan adanya perbedaan-perbedaan yang tajam mengenai aborsi antara kedua kubu tersebut, maka di dalam pernyataan akhir Konferensi Kairo 1994 tidak tercapai konsensus tentang aborsi, bahkan pernyataan akhir konferensi tersebut terkesan mendua, mungkin untuk memuaskan kubu pro dan kontra aborsi. Harus diakui bahwa itulah kesempatan pertama aborsi dibicarakan secara terbuka dalam suatu pertemuan bertaraf internasional, dimana tak seorangpun mengklaim bahwa aborsi tidak terjadi di negaranya atau komunitasnya, dan bahwa pengakuan yang secara diam-diam terhadap adanya masalah ini sudah merupakan suatu prestasi tersendiri. ${ }^{3}$

Di Indonesia aborsi merupakan salah satu masalah yang menarik untuk dibahas karena meskipun oleh hukum dilarang, tetapi aborsi tetap dilakukan, bahkan dalam jumlah yang cenderung meningkat dari tahun ke tahun. Menurut Muhadjir Darwin, ${ }^{4}$ kalau memang dilarang mestinya tersedia solusi di masyarakat untuk perempuan yang mengalami kehamilan yang tidak dikehendaki, terutama perempuan yang belum menikah (kebanyakan remaja) yang ingin meneruskan kehamilannya. Solusi seperti ini tidak tersedia. Perempuan semacam ini segera mendapatkan stigma dan dikucilkan dari keluarga, sekolah, dan masyarakat. Negara tidak menyediakan shelter kepada mereka yang memberi rasa aman dari hujatan publik. Ketiadaan alternatif shelter ini pula yang ikut mendorong perempuan-permpuan tersebut memilih jalan aborsi.

Ketimpangan yang demikian itu juga dikemukakan oleh Zamrotin $^{5}$ yang mengatakan bahwa pelarangan aborsi tanpa memberi solusi adalah tidak rasional. Jika memang dilarang, pemerintah harus membuat tempat penampungan bagi perempuan selama kehamilan yang tidak

\footnotetext{
${ }^{3}$ Siswanto Agus Wilopo. tanpa tahun. Kebijaksanaan dan Program Kesehatan Reproduksi. Program Kesehatan Reproduksi. Yogyakarta: LPKGM. HIm.4.

"Muhadjir Darwin. 2000. "Orientasi Kebijakan Kependudukan; Tinjauan Ke Depan." Makalah disampaikan pada Seminar Nasional Kebijakan Kependudukan Indonesia Tahun 2000-2015. Yogyakarta: Pusat Penelitian Kependudukan UGM. Tanggal 6 Maret. HIm. 4-5.

5Harian Kompas. "Pemerintah Perlu Fasilitasi Aborsi Aman." Tanggal 15 Desember 2000.
} 
diinginkan, serta ikut menanggung pemeliharaan anak yang dilahirkan akibat kehamilan tersebut, karena selama ini perempuan menanggung semua beban reproduksi untuk hamil maupun membatasi kehamilan.

Oleh karena itu, untuk menjembatani kesenjangan antara norma hukum yang berkaitan dengan aborsi yang berisi laranganlarangan dan sanksi pidana dengan fenomena aborsi yang cenderung meningkat di dalam masyarakat, pengaturan hukum tentang aborsi seharusnya bersikap lebih adil terhadap perempuan dengan memberikan berbagai solusi. Solusi itu berupa sarana pendukung yang menjamin rasa aman bagi perempuan yang menderita karena kehamilan yang tidak diinginkan, sehingga mereka tidak menempuh jalan pintas dengan melakukan aborsi.

\section{Pengaturan Hukum tentang Aborsi di Indonesia}

Upaya penanggulangan aborsi yang diatur di dalam KUHP sudah sangat memadai dan bahkan sangat serius dan bersungguhsungguh, sehingga tepatlah apa yang dikatakan Oemar Seno Adji 6 bahwa perundangundangan pidana di Indonesia mengenai aborsi mempunyai status hukum yang "illegal" sifatnya karena melarang aborsi tanpa kekecualian. Dengan demikian, KUHP tidak membedakan abortus provocatus kriminalis dan abortus provocatus medicinalis/ therapeuticus.

Ketentuan hukum mengenai aborsi di dalam hukum pidana Indonesia selain terdapat di dalam KUHP, juga diatur di dalam
UU No. 23 Tahun 1992 tentang Kesehatan. Di dalam KUHP ketentuan tentang aborsi terpencar dalam tiga bab sebagai berikut:

1) Bab XIV, Buku II KUHP yang mengatur "Kejahatan Kesusilaan" khususnya Pasal 283 dan 299.

2) Bab XIX, Buku II KUHP yang mengatur "Kejahatan terhadap Nyawa Orang", khususnya Pasal 346, 347, 348, dan 349.

3) Bab VI, Buku III KUHP yang mengatur "Pelanggaran Kesusilaan", yaitu Pasal 535.

Tindak pidana aborsi yang dikategorikan sebagai "kejahatan", baik "kejahatan kesusilaan" maupun "kejahatan terhadap nyawa", dapat diancam dengan sanksi pidana penjara atau denda. Sedangkan tindak pidana aborsi yang dikategorikan sebagai "pelanggaran" diancam dengan pidana kurungan atau denda seperti terlihat dalam Pasal 535 KUHP.

Terhadap tindak pidana aborsi yang digolongkan sebagai "kejahatan", jenis sanksi pidana yang dapat diancamkan adalah sebagai berikut:

1) Pidana penjara atau denda seperti terlihat dalam Pasal 283 ayat (1) dan (2), dan Pasal 283 ayat (1) dan (2), dan pasa 299 ayat (1) dan (2), kecuali Pasal 283 ayat (3) yang diancam dengan pidana penjara atau kurungan atau denda.

2) Pidana penjara saja seperti terdapat dalam Pasal 346, 347, dan 348.

3) Pidana penjara dengan pemberatan sepertiganya dan dikumulasikan dengan pidana tambahan berupa pencabutan hak untuk melakukan pekerjaan sebagai

${ }^{6}$ Oemar Seno Adji. 1984. Hukum-Hakim Pidana. Cet. Kedua. Jakarta: Penerbit Erlangga. Hlm. 191. 
dokter, bidan, atau juru obat seperti tercantum dalam Pasal 349 KUHP.

Khusus bagi kualifikasi pelaku seperti disebutkan dalam Pasal 349, terutama dokter, terdapat Kode Etik Kedokteran yang secara jelas melarang adanya aborsi. Dari segi historis, Kode Etik Kedokteran yang secara resmi dikenal dengan Lafal Sumpah Dokter Indonesia berdasarkan PP No. 26 Tahun 1960, bersumber dari.Sumpah Hippocrates ${ }^{7}$ yang hidup pada abad ke-4 SM, yang berbunyi: / will neither give a deadly drug to anyone if asked for it, nor will I make a suggestion to this effect. Similarly I will not give to a woman an abortive remedy.

Sumpah Hippocrates ini kemudian dimasukkan dalam Sumpah Dokter dalam Deklarasi Jenewa tahun 1948, dan kemudian diperbaharui dalam Deklarasi Șidney tahun 1968. Karena jasanya yang demikian besar dalam memberikan inspirași untuk perumusan sumpah dokter, maka Hippocrates hingga saat ini tetap dikenang dan dianggap sebagai bapak ilmu kedokteran modern. ${ }^{8}$

Pengaturan tentang aborsi di dalam KUHP yang merupakan warisan zaman Belanda bertentangan dengan landasan dan politik hukum Indonesia yang tercantum dalam Pembukaan UUD 1945 yaitu "melindungi segenap bangsa' Indonesia dan untuk memajukan kesejahteraan umum berdasarkan Pancasila" karena melarang aborsi tanpa pengecualian. Hal ini sangat memberatkan kalangan medis karena di dalam praktik, dokter terpaksa melakukan aborsi untuk meyelamatkan jiwa ibu, yang selama ini merupakan pengecualian di luar perundang-undangan.

Permasalahan aborsi berdasarkan pertimbangan medis baru diatur kemudian di dalam UU No. 23 Tahun 1992 tentang Kesehatan, dalam Pasal .15 beserta penjelasannya. Adapun 'Pasal 15 tersebut berbunyi:

(1) Dalam keadaan darurat sebagai upaya untuk menyelamatkan ibu hamil dan atau janinnya, dapat dilakukan tindakan tertentu.

(2) Tindakan medis tertentu sebagaimana dimaksud dalam ayat (1) hanya dapat dilakukan:

a. berdasarkan indikasi medis yang mengharuskan diambilnya tindakan tersebut;

b. oleh tenaga kesehatan yang mempunyai keahlian dan kewenangan untuk itu dan dilakukan dengan tanggung jawab profesi serta berdasarkan pertimbangan tim ahli;

c. dengan persetujuan ibu hamil yang bersangkutan atau suami atau keluarganya.

a sarana kesehatan tertentu.

(3) Ketentuan lebih lanjut mengenai tindakan medis tertentu sebagaimana dimaksud dalam ayat (1) dan (2) ditetapkan dengan Peraturan Pemerintah.

'Stephen M. Krason dan William B. Hollberg. 1973. Op. Cit.. HIm. 201.

${ }^{8}$ Soerjono Soekanto-Kartono Mohamad. Aspek Hukum dan Etika Kedokteran diIndonesia. Cet. Ke1. Jakarta: Grafity Press. HIm. 14. 
Penjelasan Pasal 15 ayat (1) berbunyi:

$$
\text { Ayat (1) }
$$

"Tindakan medis dalam bentuk pengguguran kandungan dengan alasan apapun, dilarang karena bertentangan dengan norma hukum, -norma agama, norma kesusilaan dan norma kesopanan. Namun dalam keadaan darurat sebagai upaya penyelamatan ibu dan atau janin yang dikandungnya dapat diambil tindakan medis tertentu".

\section{(Ayat 2) \\ Butir a}

"Indikasi medịs adalah suatu kondisi yang benar-benar mengharuskan diambil tindakan medis tertentu, sebab tanpa tindakan medis tertentu itu, ibu hamil dan atau janinnya terancam bahaya maut".

\section{Butir b}

"Tenaga kesehatan yang dapat melakukan tindakan medis tertentu adalah tenaga yang memiliki keahlian dan kewenangan untuk melakukannya yaitu seorang dokter ahli kebidanan dan penyakit kandungan. Sebelum melakukan tindakan medis tertentu tenaga kesehatan harus terlebih dahulu meminta pertimbangan tim ahli yang dapat terdiri dari berbagai bidang seperti medis, agama, hukum dan psikologi":

\section{Butir c}

"Hak utama untuk memberikan persetujuan pada ibu hamil yang bersangkutan kecuali dalam keadaan tidak sadar atau tidak dapat memberikan persetujuannya, dapat diminta dari sumai atau keluarganya".

\section{Butir d}

"Sarana kesehatan tertentu adalah sarana kesehatan yang memiliki tenaga dan peralatan yang memadai untuk tindakan tersebut dan telah ditunjuk. oleh Pemerintah".

\section{(Ayat3)}

"Dalam peraturan pemerintah sebagai pelaksanaan dari pasal ini dijabarkan antara lain mengenai keadaan darurat dalam menyelamatkan jiwa ibu hamil dan atau janinnya, tenaga kesehatan yang mempunyai keahlian dan kewenangan, bentuk persetujuan, dan sarana kesehatan yang ditunjuk".

Dari ketentuan Pasal 15 ayat (1) dan penjelasannya dapat disimpulkan "perbuatan yang dilarang adalah pengguguran kandungan/ aborsi kecuali dalam keadaan darurat". Hal ini berarti bahwa UU No. 23 Tahun 1992 tentang Kesehatan ${ }^{9}$ ini agak berbeda dengan KUHP yang melarang aborsi tanpa kekecualian. Dengan kata lain, UU Kesehatan tersebut mengandung larangan hukum yang sifatnya

थU No. 23 Tahun 1992 tentang Kesehatan selanjutnya dalam tulisan ini disebut dengan UU Kesehatan 
tidak mutlak terhadap tindak pidana aborsi. Pokok pikiran yang demikian itu selaras dengan konsep/doktrin yang berkembang dalam ilmu hukum pidana dan yurisprudensi yang mengakui adanya pengaruh fakktor perkembangan ilmu kedokteran dan teknologi kedokteran yang disesuaikan dengan situasi dan kondisi masyarakat Indonesia. ${ }^{10}$

Tindakan medis tertentu dalam bentuk aborsi dapat dilakukan apabila memenuhi persyaratan seperti tercantum dalam Pasal 15 ayat (2). Keadaan darurat untuk melakukan tindakan medis tertentu sebagaimana tertulis dalam Pasal 15 ayat (2) berdasarkan ketentuan Pasal 15 ayat (3) akan ditetapkan dengan Peraturan Pemerintah.

Di dalam Kode Etik Kedokteran Indonesia Bab II: Kewajiban Dokter terhadap pasien Pasal 9 tertulis: "Seorang dokter harus senantiasa mengingat akan kewajiban melindungi hidup insani. Dokter harus berusaha memelihara dan mempertahankan hidup insani. Ini berarti bahwa dokter, menurut agama, undang-undang negara maupun etik kedokteran tidak dibenarkan: 1) menggugurkan kandungan (abortus provocatus) dan 2) mengakiri hidup seorang pasien. yang menurut ilmu dan pengalaman tidak akan sembuh lagi (euthanasia).

Menurut H.M. Sulchan Sofoewan, ${ }^{11}$ abortus provocatus dapat dibenarkan sebagai tindakan pengobatan apabila itu satu-satunya jalan untuk menolong jiwa si ibu dari bahaya maut (abortus provocatus therapeuthicus). Indikasi medik ini akan berubah-ubah menurut perkembangan ilmu kedokteran. Beberapa penyakit seperti: hipertensi, tuberculose dan sebagainya tidak lagi dijadikan indikasi untuk melakukan abortus. Keputusan untuk melakukan abortus provocatus therapeuthicus harus diambil oleh sekurang-kurangnyá dua dokter dengan persetujuan tertulis dari para wanita yang hamil dan suaminya atau keluarganya yang terdekat, dan dilakukan dalam suatu rumah sakit yang mempunyai cukup fasilitas.

\section{Perkembangan Kehidupan Masyarakat tentang Aborsi di Indonesia}

Banyak faktor dan sistem nilai yang menyebabkan aborsi makin meluas di Indonesia. Pertama, kegagalan kontrasepsi bagi ibu-ibu yang mempraktikkan keluarga berencana. Tiap kontrasepsi mempunyai tingkat kegagalannya sendiri-sendiri. Masri Singarimbun ${ }^{12}$ menyatakan bahwa tingkat kegagalan berbagai kontrasepsi untuk tahun pertama adalah sebagai berikut. Tubektomi sebesar 0.04 persen, vasektomi sebesar 0,15 persen, Injeksi (progestin) sebesar 0,25 persen; pil.(kombinasi) sebesar 1 persen, IUD sebesar 1,5 persen, Kondom sebesar 2 persen, diaframa dengan spermisida sebesar

${ }^{10}$ Bambang Poernomo. 1993. "Perlindungan Hukum Aborsi Dalam Pelaksanaan Undang-Undang Kesehatan". Makalah disampaikan pada Konggres Nsional III Perhimpunan Hukum Kesehatan Indonesia di Yogyakarta. 30 Januari.

"H.M. Sulchan Sofoewan. tanpa tahun. "Aborsi Dalam Perspektif Etik Kedokteran". Yogyakàrta: Laboratorium/UPF Kebidanan dan Penyakit Kandungan FK-UGM/RSUP Dr. Sardjito. HIm. 7.

12Masri Singarimbun. 1996. Penduduk dan Perubahan. Yogyakarta: Pustaka Pelajar. HIm. 6. 
2 persen, tablet busa, jely sebesar 3-5 persen, sanggama terputus 16 persen, pantang berkala (sistem kalender, metoda lendir, metoda suhu badan basal) sebesar 2-20 persen, dan tanpa kontrasepsi sebesar 90 persen.

Kedua, menyangkut remaja dan mereka yang tidak berstatus kawin. Perubahanperubahan yang mendasar dalam sikap dan perilaku seksual dan reproduksi di kalangan remaja tampaknya sudah tambah permisif/ lebih serba boleh. ${ }^{13}$. Perubahan sikap dan perilaku seksual ini pada gilirannya mengakibatkan peningkatan masalahmasalah seksual seperti perilaku seks sebelum menikah, penyakit kelamin, aborsi, dan masalah kehamilan yang tidak dikehendaki.

-Aborsi aman dan legal merupakan salah satu kunci bagi kesehatan reproduksi. ${ }^{14}$ Konferensi Internasional Kependudukan dan Pembangunan tahun 1994 di Kairo sangat mendukung kesehatan reproduksi perempuan, meskipun sikap terhadap aborsi tetap mendua. Terlepas dari pandangan lobi anti aborsi, pandangan yang paling problematik yang dihadapi oleh konferensi itu ialah bahwa aborsi bukan merupakan metode keluarga berencana. Lalu apa keluarga berencana dari segi pandang perempuan? Bagaimana hak untuk mencegah kehamilan yang tidak diinginkan mengesampingkan hak untuk mencegah kelahiran yang tidak diinginkan? Seolah-olah keluarga berencana itu hanya bisa terlaksana sejauh rencana-rencana itu tidak menemui kegagalan. Seolah-olah kontrasepsi juga tidak pernah gagal. Dari segi pandang wanita, alat kontarsepsi apapun, tidak peduli berapa banyak alat tersebut digunakan, hanya mampu mengurangi tetapi tidak dapat menghilangkan sama sekali aborsi.

Oleh karena itu, maka Program Aksi Konferensi Internasional Kependudukan dan Pembangunan 1994 mendorong pemerintah dan organisasi-organisasi yang relevan untuk mengkaji dampak kesehatan dari aborsi tidak aman sebagai upayà untuk memberikan perhatian terhadap kesehatan umum dan mengurangi aborsi melalui perluasan dan perbaikan pelayanan keluarga berencana. ${ }^{15}$ Untuk melaksanakan rekomendasi ini para pembuat kebijakan membutuhkan informasi mengenai tersedianya pelayanan keluarga berencana serta kualitasnya, kerugian bagi kesehatan perempuan yang disebabkan oleh aborsi tidak aman dan alasan-alasan dilakukannya aborsi.

Sri Emyanti,dkk. ${ }^{16}$ menyatakan bahwa aborsi pada saat ini tetap merupakan perdebatan di Indonesia. Seringkali perdebatan tersebut terpusat pada dua kutub. Kutub pertama berargumentasi bahwa bila reproduksi mierupakan hak, maka aborsi yang aman

${ }^{13}$ Masri Singarimbun. 1994. "Beberapa Aspek Aborsi". POPULI. 5 (2). Hlm. $39-51$.

${ }^{14}$ Marge Berer. "Making Abortion Safe and Legal: The Ethics and Dynamics of Change. Reproductive Health Matters. Nov. (2). HIm. 5-10.

is Stanley, K. Henshaw et al. 1999. "The Incidence of Abortion Worldwide". International Family Planining Perspectives. January (25). Him. 30.

${ }^{16}$ Sri Emyanti, dkk. 1997 Aborsi, Sikap dan Tindakan Para Medis. Yogyakarta: PPKUGM-Ford Foundation. HIm. 5.' 
menjadi hak pula. Kutub kedua mempertahankan aborsi sebagai pelanggaran nilai sosial. Fakta menunjukkan bahwa kita tidak berada pada kedua-duanya. Palayanan aborsi tidak ada, tetapi aborsi dilakukan secara diam-diam dan mempunyai ancaman ketidakamanan.

Sejak Konferensi Internasional Kependudukan dan Pembangunan 1994, aborsi tidak aman merupakan masalah kesehatan yang mendapat perhatian secara global. Di banyak negara berkembang wanita sangat sedikit mengetahui dan mempunyai akses terhadap metode kontrasepsi dan sebagai akibatnya mengalami kehamilan yang tidak diinginkan. Karena kerasnya hukum aborsi dan keterbatasan pengetahuannya terhadap metode untuk mencegah kehamilan, banyak wanita melakukan aborsi dalam kondisi yang tidak aman. Diperkirakan di seluruh dunia setiap tahun dilakukan 20 juta aborsi tidak aman dan mengakibatkan kematian 70.000 wanita dan kebanyakannya terjadi di negara-negara yang sedang berkembang. $\mathrm{Di}$ Afrika khususnya, diperkirakan 3.7 juta aborsi tidak aman dilakukan setiap tahun dan mengakibatkan kematian sekitar 23.000 wanita. ${ }^{17}$

Sampai tahun 1998 di Indonesia diperkirakan sejuta aborsi tidak aman dilakukan setiap tahun. Hal ini terungkap di dalam diskusi terbatas mengenai aborsi tidak aman yang diselenggarakan Perkumpulan Keluarga
Berencana Indonesia (PKBI) tanggal 24 April 1998 di. Jakarta. ${ }^{18}$ Penanganan yang layak atas aborsi yang tidak aman (unsafe abortion) merupakan cerminan kepedulian negara terhadap penegakan hak-hak perempuan, khususnya hak reproduksi. Hal ini masih merupakan retorika, karena perlindungan hukum pada praktisi medis di bidang kesehatan reporduksi pun tidak jelas. Oleh karena itu, diskusi mengenai topik yang sama ini akan terus dilakukan sampai dihasilkan satu strategi yang tepat dan menyeluruh untuk memberdayakan masyarakat dan praktisi medis, serta melakukan rekonstruksi atas sejumlah produk hukum yang bersifat ambivalen dalam masalah ini.

Aborsi tidak aman merupakan salah satu kontributor angka kematian ibu. (AKI). Oleh karena itu Pribakti B. ${ }^{19}$ mengusulkan agar AKI dapat diturunkan melalui Gerakan Sayang Ibu seperti terlihat dalam kutipan berikut ini:

"Dalam upaya itu seyogyanya persoalan aborsi mendapat perhatian yang serius karena aborsi adalah manifestasi dari kehamilan yang tidak diinginkan dan sekaligus merupakan sesuatu yang ilegal dan peka di Indonesia. Kalau konsekuen dalam usaha menekan AKI, maka hal itu dapat diabaikan, karena seperti diketahui aborsi yang dilakukan oleh tenaga yang tidak profesional mempunyai risiko yang sangat tinggi."

${ }^{17}$ Paulina Makinwa-Adebuyose, et. al. 1997. "Nigerian Health Professionals' Perceptions About Abortion Practice". International Health Family Planning Perspectives. December (23). HIm. 155.

${ }^{18} \mathrm{Harian}$ Kompas. "Penanganan Abortus Cermin Kepedulian Hak Reproduksi". Tanggal 26 April 1998.

${ }^{19}$ Pribakti B. "Gerakan Sayang Ibu". Harian Jawa Pos. Tanggal 1 September 1997. 
Kemungkinan besar angka aborsi meningkat akibat krisis ekonomi yang berkepanjangan serta kurangnya pengetahuan tentang aspek legalitas, terutama kasus aborsi yang dilakukan secara tidak aman. ${ }^{20}$ Peningkatan ini sepintas terlihat aneh jika diingat bahwa pemerintah dan publik bersikap lebih keras terhadap para pelaku aborsi. Seperti diketahui banyak dokter yang yang melakukan praktik aborsi ditangkap dan dipidana. Media massa pun cenderung menyalahkan para dokter tersebut.

Gerakan Sayang lbu ini merupakan suatu fenomena yang menarik dan cukup mendapat perhatian mantan Menteri Kesehatan Farid Anfasa Moeloek sehingga dalam Pertemuan IImiah Tahunan XI POGI (Perkumpulan Obstetri dan Ginekologi Indonesia) tanggal 11 juli 1999 di Semarang, beliau ${ }^{21}$ mengatakan:

"Pergantian UU Aborsi yang sudah tua menimbulkan pro-kontra. Karena itu Depkes akan menyeleksi klinik dan rumah sakit tertentu yang khusus melaksanakan aborsi. Penunjukan klinik khusus yang sifatnya komprehensif itu tidak hanya dilihat dari segi medis, tetapi juga mempertimbangkan segi sosiobudaya dan agama".

Berkaitan dengan AKI sebagaimana diutarakan di atas, perlu diperhatikan bahwa Siswanto Agus Wilopo ${ }^{22}$ menggunakan istilah "angka kematian maternal" (AKM). Dikatakan bahwa AKM di negara maju sudah sangat jarang ditemui. Di Inggris, dari 100,000 kelahiran hidup hanya dijumpai 9 kematian maternal, sedangkan di indonesia masih berkisar 390 kematian ibu. Di Indonesia, AKM relatif tidak mengalami perubahan selama 10 tahun terakhir. Bahkan oleh UNICEF, AKM tahun 1995 diperkirakan 650 per 100.000 kelahiran hidup.

Sehubungan dengan aborsi tidak aman, Siswato Agus Wilopo ${ }^{23}$ juga menegaskan bahwa ketersediaan pelayanan untuk mengatasi komplikasi aborsi dan perawatan pasca aborsi hendaknya diatur dengan kebijaksanaan yang tegas. Kebijakan nasional untuk mendorong agar tidak terjadi aborsi yang tidak aman (unsafe abortion) dilakukan dengan cara antara lain: a) promosi dan proteksi terhadap kehamilan yang belum diharapkan; b) mengenalkan bahaya resiko dari aborsi yang tidak aman; dan c) mempromosikan agar kesadaran tentang pentingnya dan memperoleh pengobatan dari komplikasi aborsi. Dengan menurunkan aborsi yang tidak sehat maka sekitar 13 persen kematian maternal dapat dicegah. Di Indonesia, kematian karena aborsi tak sehat ini lebih besar presentasinya dibanding dengan angka-angka internasional (20-30 persen).

Dugaan bahwa jumlah aborsi akan meningkat karena krisis ekonomi ternyata benar, karena Azrul Azwar ${ }^{24}$ di Musyawarah

${ }^{20}$ Zarfiel Tafal, et al. \{eds).1998. Op. Cit. HIm.2.

"Harian Kompas. "Perlu Klinik Komprehensif untuk Aborsi". 13 Juli 1979.

"Siswanto Agus Wilopo. "Kebijakan Penurunan Kamatian Maternal". Makalah disampaikan pada Seminar Nasional "Kebijakan Kependudukan Indonesia Tahun 2000-2015". Yogyakarta: Pusat Penelitian Kependudukan UGM. 6 Maret 2000. Him. 1.

${ }^{23}$ /bid. Hlm. 18.

${ }^{24}$ Harian Kompas. "PKBI Promosikan Aborsi Aman." Tanggal 23 Agustus 2000. 
Nasional $\mathrm{XI}$ 'Perkumpulan Keluarga Berencana Indonesia (PKBI) 'tanggal 28 Agustus 2000 di Jakarta mengatakan bahwa angka aborsi di Indonesia 2,3 juta per tahun sebagai akibat meningkatnya jumlah kehamilan' yang tidak diinginkan yang disebabkan karena perubahan gaya hidup akibat kemjauan informasi, adanya pergaulan bebas dan keggagalan alat kontrasepsi. Oleh karena itu, dalam kesempatan tersebut PKBI mempromosikan aborsi aman dan legal untuk kasus-kasus tertentu di luar indikasi medis, sebagaimana diatur dalam Pasal 15 UU Kesehatan. Promosi yang demikian itu perlu dilakukan mengingat tingginya AKI karena aborsi tidak aman.

Dalam kesempatan tersebut beliau ${ }^{25}$ juga menegaskan bahwa aborsi aman harus dilakukan dengan alasan kuat dan batas waktu yang tegas. Mengenai batas waktu, sebagian ulama Islam berpendapat bahwa aborsi yang dilakukan sebelum 120 hari hukumnya haram dan sebagiannya lagi berpendapat boleh. Batasan 120 hari dipakai sebagai tolok ukur boleh-tidaknya aborsi dilakukan mengingat sebelum 120 harijanin belum ditiupkan ruhnya yang berarti belum bernyawa. ${ }^{26} \mathrm{PKBI}$ mengadvokasikan aborsi sampai delapan minggu kehamilan, sesudah itu seyogyanya aborsi tidak dilakukan lagi. Untuk itu telah terbentuk suatu Komisi yang terdiri dari jajaran Depkes, IDI dan PKBI untuk menyusun naskah akademik mengenai aborsi aman. Selain itu sudah ada upaya untuk meninjau dan mengubah sumpah dokter yang berbunyi: "Kami menghormati makluk' insani sejak pembuahan" menjadi "Kami menghormati makhluk insani sejak kehidupan".

Menurut Budi Wahyuni27 kata "aman" memang dapat dimaknai lebih dari satu arti. Aman berarti sehat, karena dilakukan oleh tenaga profesional (dokter) bukan oleh dukun: Mengingat sampai sekarang ini belum ada peraturan perundangan maka aman dapat berarti tidak ada tuntutan hukum, baik bagi perempuan yang melakukan aborsi maupun tenaga medis yang membantu. Aman juga dapat berarti tidak perlu sembunyi-sembunyi, karena ada tempat khusus yang menyediakan layanan aborsi bagi setiap perempuan yang membutuhkan, karena aborsi merupakan bagian dari hak reproduksi perempuan.

Dalam dialog publik mengenai Hak Reproduksi dan Aborsi yang Aman yang diselenggarakan di Jakarta tanggal 14 Desember 2000, aktivis perempuan Myra Diarsi ${ }^{28}$ mengatakan bahwa saat ini wacana di tingkat masyarakat digiring dengan mempertentangkan aborsi dengan kepentingan agama sehingga terjadi saling menghujat di masyarakat. Padahal, yang terjadi sebenarnya adalah kelalaian negara, dalam hal ini Pemerintah Indonesia yang memilih bentuk negara sekuler namun menyerahkan urusan

${ }^{25}$ /bid.

${ }^{26}$ Laily Hanifah. "Aborsi Ditinjau Dari Tiga Sudut Pandang."Gender \& Kesehatan. Edisi Khusus. (8) No.1. Januari-Pebruari 2001. HIm. 4-5.

${ }^{27}$ Budi Wahyuni. "Aborsi dan Kegagalan Kontrasepsi". Makalah disampaikan pada Seminar bulanan Pusat Penelitian Kependudukan UGM. 21 September 2000. HIm. 1.

${ }^{2}{ }^{2}$ Harian Kompas. "Pemerintah Perlu Fasilitasi Aborsi Aman". Tanggal 15 Desember 2000. 
privat ke pada kekuasaan marginal. Oleh karena itu, yang harus dilakukan adalah menagih pemerintah untuk bersikap jelas dan transparan dalam masalah aborsi.

Dari paparan di atas, dapat dikatakan bahwa perubahan dalam masyarakat Indonesia ini akan menimbulkan permasalahan yang memungkinkan jus constitutum tentang aborsi yang saat ini illegal sifatnya berubah menjadi jus constituendum tentang aborsi yang legal dengan persyaratan tertentu yaitu aborsi aman.

\section{Tuntutan Perkembangan Masyarakat terhadap Pengaturan Hukum tentang Aborsi di Indonesia}

Usaha pembaharuan hukum di Indonesia yang sudah dimulai sejak lahirnya UUD 1945 tentunya tidak boleh dilepaskan dari politik hukum yang bertugas untuk meneliti perubahan-perubahan yang perlu diadakan terhadap hukum agar supaya memenuhi kebutuhan-kebutuhan baru di dalam masyarakat. Politik hukum tersebut meneruskan arah perkembangan tertib hukum, dari ius constitutum yang bertumpu pada kerangka landasan hukum yang dahulu menuju ke penyusunan ius constituendum atau hukum pada masa yang akan datang. ${ }^{29}$

Jelas bahwa perubahan yang terjadi di dalam masyarakat menyangkut aborsi ini berpengaruh pula terhadap politik hukum yang berkaitan dengan aborsi di Indonesia. Menurut Sunaryati Hartono ${ }^{30}$ 'politik hukum Indonesia. di satu pihak tidak terlepas dari realitas sosial dan tradisional yang terdapat di Indonesia sendiri. Di lain pihak, sebagai salah satu anggota masyarakat dunia, politik hukum Indonesia tidak terlepas pula dari realitas dan politik hukum international. Dengan demikian faktor-faktor yang akan menentukan politik hukum tidak semata-mata ditentukan oleh apa yang dicita-citakan atau tergantung pada kehendak pembentuk hukum, praktisi atau para teoritisi belaka, akan tetapi ikut ditentukan pula oleh kenyataan serta perkembangan hukum di lain-lain'negara serta perkembangan hukum internasional.

Dalam konteks ilmu hukum, maka politik hukum merupakan salah satu cabang dari ilmu hukum, sedangkan dalam konteks pembangunan hukum, maka menurut Mulyana W. Kusuma ${ }_{1}{ }^{31}$ politik hukum nasional secara harafiah dapat diartikan sebagai kebijaksanaan hukum (legal policy) yang hendak diterapkan atau dilaksanakan secara nasional oleh suatu pemerintahan negara tertentu. Politik hukum nasional bisa meliputi: a) pelaksanaan ketentuan hukum yang telah ada secara konsisten; b) pembangunan hukum yang intinya adalah, pembangunan terhadap ketentuan hukum yang telah ada, yang dianggap usang, dan penciptaan ketentuan hukum baru yang diperlukan untuk

${ }^{29}$ Soehardjo, Ss. tanpa tahun. Politik Hukum dan Pelaksanaannya Dalam Negara Republik Indonesia. Fakultas Hukum Undip. HIm. 2.

${ }^{30}$ Sunaryati Hartono. 1991. Politik Hukum Menuju Satu Sistem Hukum Nasional. Bandung: Alumni. HIm. 1.

${ }^{31}$ Kusumah, Mulyana W. 1986. Perspektif,teori dan kebijaksaan hukum. Jakarta: Penerbit CV Rajawali. HIm. 42-43. 
memenuhi tuntutan perkembangan masyarakat; c) penegasan fungsi lembaga penegak - atau pelaksana hukum, dan pembinaan anggotanya; d) meningkatkan kesadaran hukum masyarakat menurut persepsi kelompok elit pengambil kebijakan.

Menurut Sudarto ${ }^{32}$ politik hukum merupakan kebijakan dari negara melalui badan-badan yang berwenang untuk menetapkan peraturanperaturan yang dikehendaki yang diperkirakan bisa digunakan untuk mengekspresikan apa yang terkandung dalam masyarakat dan untuk mencapai apa yang dicita-citakan. Di tempat lain Sudarto ${ }^{33}$ mengatakan bahwa politik hukum adalah usaha untuk mewujudkan peraturan-peraturan yang baik sesuai dengan keadaan dan situasi pada suatu waktu.

Moh. Mahfud $\mathrm{MD}^{34}$ mengatakan bahwa politik hukum secara sederhana dapat dirumuskan sebagai kebijaksanaan hukum (legal policy) yang akan atau telah dilaksanakan secara nasional oleh pemerintah; mencakup pula pengertian tentang bagaimana politik mempengaruhi hukum dengan cara melihat konfigurasi kekuatan yang ada di belakang pembuatan dan penegakan hukum itu. Disini hukum tidak dapat hanya dipandang sebagai pasal-pasal yang bersifat imperatif atau keharusan-keharusan yang bersifat das sollen, melainkan harus dipandang sebagai subsistem yang dalam kenyataan (das sein) bukan tidak mungkin sangat ditentukan oleh politik, baik dalam perumusan materi dan pasal-pasalnya maupun dalam implementasi dan penegakannya.

Berdasarkan pengertian politik hukum yang demikian itu, maka Sudarto ${ }^{35}$ kemudian mengatakan bahwa melaksanakan "politik hukum pidana" berarti mengadakan pemilihan untuk mencapai hasil perundangan pidana yang paling baik dalam arti memenuhi syarat keadilan dan dayaguna. Berdasarkan pendapat tersebut, maka beliau ${ }^{36}$ selanjutnya mengatakan bahwa politik hukum pidana termasuk salah satu bidang yang perlu mendapat perhatian. $\mathrm{Hal}$ ini disebabkan karena untuk dapat menerapkan aturanaturan pidana secara tepat para petugas hukum tidak cukup hanya mempelajari ilmu hukum pidana, yang hanya melihat segi peraturan hukumnya saja dari suatu kejahatan, akan tetapi juga harus memahami gejala-gejala dari kehidupan manusia yang terletak di belakang abstraksi-abstraksi yuridis, dan hal terakhir ini diberikan oleh krimnologi.

Bertolak dari pengertian politik hukum pidana yang demikian itu, Barda Nawawi Arief ${ }^{37}$ mengatakan bahwa melaksanakan "politik hukum pidana" atau "kebijakan hukum pidana" berarti "kebijakan penanggulangan dengan hukum pidana". Oleh karena itu, politik hukum pidana dapat mencakup ruang lingkup

\footnotetext{
${ }^{32}$ Sudarto. 1983. Hukum Pidana dan Perkembangan Masyarakat.Jakarta: Sinar Baru. HIm. 20.

${ }^{33}$ Sudarto. 1986. Kapita Selekta Hukum Pidana."Bandung: Alumni. HIm. 151.

${ }^{34}$ Moh. Mahfud MD. 1998. Politik Hukum Di Indonesia." Jakarta: LP3ES. HIm.. 2-3.

${ }^{35}$ Sudarto. 1986..Op. Cit Him. 153.

${ }^{38}$ Sudarto. 1990. Hukum Pidana I. Semarang: Yayasan Sudarto FH-Undip. HIm. 15.

${ }^{37}$ Barda Nawawi Arif. 1991. Kebijakan Kriminal (Criminal Policy), Bahan Penataran Kriminologi. Bandung: Universitas Katolik Parahyangan. Him. 8.
} 
kebijakan di bidang hukum pidana material, hukum pidana formal, dan hukum pelaksanaan pidana. Dengan demikian, politik hukum pidana yang berkaitan dengan aborsi adalah kebijakan menentukan perangkat hukum pidana tentang aborsi yang baik dan sesuai dengan situasi dan perkembangan ilmu pengetahuan serta penggunaan teknologi kesehatan yang maju saat ini.

Dari apa yang dikemukakan di atas, dapat dikatakankan bahwa pendekatan yang rasional memang merupakan pendekatan yang seharusnya melekat pada setiap langkah kebijakan. Hal ini merupakan konsekuensi logis, karena menurut Sudarto ${ }^{38}$ dalam melaksanakan politik hukum orang mengadakan penilaian dan melakukan pemilihan dari sekian banyak alternatif yang dihadapi yang menjadi dasar analisis dalam tulisan ini.

Berkaitan dengan pengaturan hukum, termasuk di dalamnya pengaturan hukum tentang aborsi, menurut $E$. Utrecht ${ }^{39}$ negara bertugas menjamin adanya kepastian dalam hubungan antara anggota masyarakat yang satu dan yang lain. Pemerintah negara (staatsoverheid) sebagai alat pemerintahan tertinggi dalam masyarakat sudah logis menjadi alat satu-satunya untuk dapat mempertahankan pergaulan hukum umum (algemene rechtsverkeer) dalam masyarakat. Pemerintah negara adalah alat satu-satunya untuk menjamin adanya kepastian hukum (rechtszekeheid) dalam pergaulan sosial: Supaya dapat mencapai tujuan ini, maka pemerintah negara diberi kekuasaan mengadakan beberapa tindakan, antara lain menjatuhkan hukuman atas mereka yang secara kejam telah melanggar kaidah-kaidah yang dibuat untuk mempertahankan tatatertib umum dan yang dibela oleh pemerintah negara itu.

Meskipun hukum aborsi dalam ius constitutum menetapkan hak dan kewajiban, namun karena pengaruh "perkembangan kehidupan masyarakat" terhadap "pengaturan hukum tentang aborsi", maka berdasarkan teori Roecoe Pound bahwa Law is a tool/instrument of social engineering ${ }^{40}$ dan berdasarkan penilaian serta pemilihan sehubungan dengan pelaksanaan politik hukum sebagaimana diutarakan Sudarto di atas, dapat dikatakan bahwa pengaturan hukum tentang aborsi di masa datang (Ius Constituendum), akan ada tiga pilihan yaitu mengikuti perkembangan masyarakat, merubah perkembangan masyarakat, atau menolak perkembangan masyarakat.

Dari tiga pilihan tersebut, analisis dalam tulisan ini memperlihatkan kecenderungan dalam pengaturan hukum tentang aborsi yaitu de normatieve kracht van de feiten, de feitelyke kracht van de normen yang menunjukkan bahwa perkembangan kehidupan masyarakat dapat merubah ketentuan hukum tentang aborsi.

${ }^{38}$ Sudarto. 1996. Op. Cit: HIm. 153.

${ }^{39}$ E. Utrecht. 1994. Hukum pidana 1. Surabaya: Penerbit Pustaka Tinta Mas. HIm. 156-157.

${ }^{40}$ Satjipto Rahardjo. 1982. Ilmu Hukum. Bandung. Penerbit Allumni. HIm. 299. 
Paulinus Soge. Pengaruh Perkembangan Kehidupan Masyarakat terhadap...

\section{Simpulan}

Berdasarkan anälisis sebagaimana dikemukakan di atas maka dapat diambil kesimpulan bahwa "perkembangan kehidupan masyarakat Indonesia (Das Sein) dapat merubah pengaturan hukum tentang aborsi dari yang bersifat illegal menjadi legal (Das Sollen) ${ }^{n}$; dengan persyaratan tertentu yaitu aborsi aman (safe abortion) untuk menghindarkan wanita melakukan aborsi tidak aman (unsafe abortion) yang sering mengakibatkan kematian maternal.

\section{Daftar Pustaka}

Agus Wilopo, Siswanto. tanpa tahun, Kebijaksanaan dan Program Kesehatan Reproduksi. Program Kesehatan Reproduksi. Yogyakarta: LPKGM.

Bere, Marge. 1995. "Making Abortion Safe and Legal: The Ethics and Dynamics of Change." Reproductive Health Matters. Nov; (2).

Emiyanti, Sri, dkk. 1997.Aborsi, Sikap dan

Tindakan Para Medis. Yogyakarta: Kerjasama Pusat -Penelitian kependudukan dengan Ford Foundation.

Hanifah, Laily. 2001."Aborsi Ditinjau Dari Tiga Sudut Pandang." Jender \& Kesehatan. Januari-Pebruari Vol. 8 (Edisi Khusus). No.1.

Hartono, Sunaryati. 1991.Politik Hukum Menuju. Satu . Sistem. Hukum Nasional..Bandung: Alumni.
Henshaw; Stanley K. et al. 1999. "The Incidence of Abortion Worldwide." International Family Planning Perspectives. January (25).

Krason, Stephen M. and William B. Hollberg. 1973. "The Law and History of Abortion: The Supreme Court Refuted." Dalam J. Douglas Butler and David F. Walbert (eds). 1973. Abortion, Medicine, and The Law New. York.: Facts On File Publications.

Mahfud, MD. Moh. 1998. Politik Hukum Di Indonesia. Jakarta: Pustaka LP3S Indonesia.

Makinwa-Adebuyose, Paulina, èt. al. 1997. "Nigerian Health Professionals' Per- ceptions About Abortion Practice". International Family Planning Perspectives. December (23).

Mulyana W., Kusumah. 1986. Perspektif, Teori dan Kebijaksanaan Hukum. Jakarta: 'Penerbit CV Rajawali.

Pearson, J.D., Albert M. and P.aul M. Kurtz, J.D. 1973. "The Abortion Controversy: A 'Study in Law and Politics", dalam J. Douglas Butler and David F. Walbert, (Eds) "Abortion, Medicine, And The Law". Third Ed.

Rahardjo, Satjipto. 1982. Ilmu, Hukum. 'Bandung: Penerbit Alumni.

Seno Adji, Oemar H. 1980. Húkum-hakimPidana. Cet. 2. Jakarta: Penerbit LP3S.

Singarimbun, Masri. 1994. Beberapa Aspek Aborsi. POPULI 5(2).

1996. Penduduk dan Perubahan.

Yogyakarta: Pustaka Pelajar. 
Soehardjo, Ss. Tanpa Tahun. Politik Hukum $\therefore$ dan Pelaksanaannya dalam Negara Republik Indonesia. Semarang: Fakultas Hukum Undip.

Soekanto, Seerjono - Kartono Mohammad. 1983. Aspek Hukum dan Etika Kedokteran di Indonesia.. Jakarta: Grafity Press.

Sofoewan,.Sulchan H.M. tanpa tahun. Aborsi Dalam Perspektik Etik Kedokteran. Yogyakarta: Laboratorium/UPF Kebidanan dan Penyakit Kandungan. Fak. Kedokteran.UGM.

Sudarto, 1983. Hukum Pidaña dan Perkembangan Masyarakat. Bandung: Sinar Baru.

1986. Kapita'Selekta Hukum Pidana:

: Bandung: Penerbit Alumni.

—. 1990. Hukum Pidana I. Semarang: $\therefore$ Yayasan Sudarto. FH-Undip.

Tafal, Zarfiel, eds. 1998. Aborsi, Di BayangBayang Kematian Ibu. Jakarta: Percetakan. Wirabakti.

Utrecht', E' 1994. Hukum Pidanal. Surabaya:

Penerbit Pustaka Tinta Màs.

Agus Wilopo, Siswanto dkk 2000. "Kebijakan Penurunan Kematian Maternal," Makalah disampaikan pada Seminar Kebijakan Kependudukan Indonesia Táhun 2000-2015. Yogyakarta: - Pusat Penelitian Kependudukan UGM. 6 Maret:
Darwin, Muhadjir. 2000. "Arah Kebijakan Kependudukan: Tinjauan Ke Depan", Makálah.disampaikan dalam Seminar Kebijakan Kependudukan Indonesia Tahun .2000-2015. Yogyakarta: Pusat Penelitian Kependudukan UGM. 6 Maret.

Nawawi Arief, Barda. 1991. Kebijakan Kriminal (Criminal Policy). Bahan Penataran Kriminologi.Bandung: Universitas Katolik Parahyangan. 9-13 September.

Poernomo, Bambang. 1993. "Perlindungan Hukum Aborsi Dảam Pelaksanaan Undang-Undang Kesehatanan". Makalah disampaikan pada Konggres Nasional III Perhimpunan Hukum $\therefore$ Kesehatan Indonesia di Yogyakarta, 30 Januari.

Wahyuni, Budi, 2000. "Aborsi dan Kegagalan Kontrasepsi 'IUD", Makalah disampaikan pada Seminar Bulanan PPK UGM, 21 September.

Pribakti, B. 1997: "Gerakan Sayang Ibu". JAWA POS. 1 September.

Harian Kompas. "Penanganan Abortus Cermin Kepedulian Hak Reproduksi". 26 April 1998.

- . Perlu Klinik Kompreḥensif untuk Aborsi". 13 Juli 1999.

. "PKBI Promosikan Aborsi Aman". 23 Agustus 2000.

"Pemerintah Perlu Fasilitasi Aborsi: Aman". 15 Desember 2000. 